\title{
Energy related outsourcing: - The case of ESCOs in the Swedish pulp and paper industry
}

Patrik Thollander and Mikael Ottosson

\section{Linköping University Post Print}

N.B.: When citing this work, cite the original article.

(C2011 IEEE. Personal use of this material is permitted. However, permission to reprint/republish this material for advertising or promotional purposes or for creating new collective works for resale or redistribution to servers or lists, or to reuse any copyrighted component of this work in other works must be obtained from the IEEE.

Patrik Thollander and Mikael Ottosson, Energy related outsourcing: - The case of ESCOs in the Swedish pulp and paper industry, 2011, IEEE International Technology Management Conference, 329-337.

http://dx.doi.org/10.1109/ITMC.2011.5995962

Postprint available at: Linköping University Electronic Press

http://urn.kb.se/resolve?urn=urn:nbn:se:liu:diva-70385 


\title{
Energy related outsourcing - The case of ESCOs in the Swedish pulp and paper industry
}

\author{
Patrik Thollander, Mikael Ottosson \\ Linköping University \\ Linköping, Sweden \\ patrik.thollander@liu.se; +46-13-28 5745
}

\begin{abstract}
Industrial energy efficiency is stated as a major means of reducing the threat of increased global warming, caused by human use of fossil fuels. Energy service companies (ESCOs) have been expected to play an important role in promoting energy efficiency in different sectors of the economy, including industry. Energy related outsourcing in the complex energy intensive pulp and paper industry, with a continuous production process, represents one of the more challenging types of industrial outsourcing. This paper studies the role of ESCOs as a method to promote energy efficiency in the Swedish pulp and paper industry. A questionnaire was used, complemented by in-depth interviews with mill executives in order to gain more knowledge of the issue. The main conclusion from this paper is that the utilization of ESCOs in the pulp and paper industry is higher in activities with a lower level of energy integration in the production process, and on the contrary, the utilization of ESCOs is lower with a higher level of energy integration in the production process. Since the PPI is a mature industry with a globally well-known and wellspread technique, results from this paper, may plausibly be generalized for PPIs in other countries as well.
\end{abstract}

\section{Introduction}

Industrial energy efficiency is stated as a major means of reducing the threat of increased global warming, caused by human use of fossil fuels (IPCC, 2007). Energy service companies (ESCOs) have been expected to play an important role in promoting energy efficiency in different sectors of the economy, including industry (Vine, 2005). An ESCO is a company that is engaged in running different energy related business activities such as facilities, boilers, etc. The idea behind an ESCO is that a company outsources parts of its business that are not considered core business areas to the ESCO that takes over and operates this activity. This in turn may lead to increased cost and energy effectiveness.

The Swedish pulp and paper industry (PPI) is a substantial user of energy, accounting for about 2 percent of the EU-25 industrial energy use and almost 50 percent of Swedish industrial energy use (SEA, 2007a, Eurostat, 2007). The large use of energy in the Swedish PPI makes the industry particularly important in terms of energy efficiency. Previous research has emphasized an increasing potential and use of ESCOs by the Swedish PPI, the main driving force behind energy related outsourcing being that the PPIs are increasingly focusing their attention and efforts on their core business, which do not include energy (Möllersten and Westermark, 2001). In 2000 there were 14 known outsourcing agreements between ESCOs and Swedish PPIs (Möllersten and Sandberg, 2004). However, later research in the industry found that ESCOs were ranked lowest among all the driving forces for energy efficiency included in the study (Thollander and Ottosson, 2008). Analyzing and evaluating the role of ESCOs in the Swedish PPI is of importance for a number of reasons. First, the Swedish PPI is a major user of energy making various energy efficiency means in the industry attractive. Second, the outsourcing of energy related activities to ESCOs has been stated as one of the major means of aiming to reduce the European Union's use of energy by 9 percent, making different case studies of ESCOs of considerable importance (EC, 2006). Third, the PPI is in several aspects an extraordinary industry with a continuous production process, where production disruptions are very costly, making any change in the process a high risk project. Energy related outsourcing of production related activities such as boilers, may therefore be a far-reaching form of outsourcing. Different reports have, however, stated that the entire paper production could be outsourced and managed through a customer interface (Ernst \& Young, 2007). This accentuates the need for research on the role of energy-related outsourcing, in particular ESCOs in the Swedish PPI. The aim of this study is to describe and analyze the role of ESCOs as a method to promote energy efficiency in the Swedish pulp and paper industry.

\section{The Swedish pulp and paper industry}

About $80 \%$ of the pulp and paper produced in the Swedish PPI is exported to international markets. In 2005, Sweden was the third largest exporter of paper products and the fourth largest exporter of pulp in the world (SFI, 2005). The industry accounts for about $50 \%$ of the aggregated domestic industrial energy use, which in turn represents about $6 \%$ of the Swedish aggregated production value. In Sweden there are about 60 mills, which employ about 27,500 people (SFI, 2005; SEA, 2007a). About $40 \%$ of the mills are integrated pulp and paper mills, $40 \%$ are non-integrated paper mills, and $20 \%$ are market pulp producers (DS, 2001). Historically, vertical integration between pulp and paper production has increased, while there has been a decline in the production of market pulp (Bjuggren, 1985).

There are three basic types of production of pulp: mechanical, chemical, and chemical-thermo mechanical pulp production (CTMP). The chemical pulp process mainly uses biomass as primary energy source, while the mechanical pulp process uses more electricity. The Swedish PPI uses about 50 $\mathrm{TWh} /$ year biomass, 22,5 TWh/year electricity and 7,3 $\mathrm{TWh} /$ year fossil fuels. The ongoing trend since the 1970s has been that the industry has gradually grown less dependent on fossil fuels due to increased energy efficiency while the use of electricity has increased (SCB, 2006). The chemical pulp mills also annually generate about $5 \mathrm{TWh}$ /year electricity by using back pressure (SFI, 2007). 
The industry is characterized by heavy capital intensive production investments, e.g. a paper machine costs about 200500 million EURO to install and a new recovery boiler costs about 150 - 200 million EURO. Pay-off periods for these types of investments are often far in excess of 20 years. The manufacturing of paper is carried out at speeds of about 100 $\mathrm{km} / \mathrm{h}$ (Laestadius, 1998). This means that unplanned production disruptions are very costly and that the few planned stops in the continuous production processes make any change in the process a high risk project.

\section{Method}

Previous research has emphasized different forms of energy related collaborations and outsourcings in the Swedish PPI (Möllersten and Westermark, 2001; Möllersten and Sandberg, 2004; Wolf and Peterson, 2007). The Wolf and Peterson (2007) study spotted that half of the studied 59 mills had some type of cooperation, such as waste heat cooperation between PPIs and district heating companies. Internationally, there has also been outsourcing within the PPI of power generation, energy management, water and waste water treatment, industrial gas, and air and steam operations (Hrickiewicz, 1999). In one case that was given a lot of attention in the press, three pulp mills in British Columbia outsourced their entire maintenance operations to a service company (Greenbaum, 2001). As stated above, several outsourcing agreements between ESCOs and PPIs exist today.

This paper, however, investigates the role of ESCOs as a method of promoting energy efficiency in the Swedish PPI. Examples of such outsourcing projects include the outsourcing of a biofuel-fired boiler in a pulp and paper mill. This paper will not focus on other forms of outsourcing of non-core business related areas such as IT services.

Inspired by Yin (2003), a multiple case study was conducted of the Swedish PPI using a questionnaire and indepth interviews, annual reports, energy audits and other forms of internal documents. Yin (2003) argues that case study research is particularly advantageous when 'how' or 'why' questions are asked about a contemporary set of events over which the investigator has little or no control (Yin, 2003). Moreover, multiple case studies are preferred as increased number of cases increases the study's validity (Merriam, 1998). Generalizations from case studies are made using 'analytic generalization'. Analytic generalization means that theories sprung from case study research may be of a nature proved to hold or to not hold in other cases, e.g. it is not possible to generalize findings to the all other industries stating the use or not of ESCOs decreases or increases the energy efficiency and profitability. However, what is possible is to state is a theoretical proposal regarding the use of ESCOs within the Swedish PPI which might also be applicable to PPIs in other countries as well as other similar types of process industries such as the chemical industry, etc.

The questionnaire was sent out to the person in charge of energy issues, such as the technical manager, energy manager and/or environmental manager, asking the respondent to, among other things, rank their view of different information sources and the mill's/company group's priority of the energy issue. The ranking of information sources have previously been presented in Thollander and Ottosson (2010). When presenting the results in this paper, the answers from the questionnaire and the interviews were translated from Swedish to English. The questionnaire was sent to 59 mills and 40 were returned, a response rate of $68 \%$. A list of respondents were gained from the Swedish Energy Agency's contact list for the Swedish long term agreements (LTA) programme PFE (Programme for improving energy efficiency in energyintensive industries) as well as from the industry organization, the Swedish Forest industry. These organizations were informed of the results as a validation. As regards the in-depth interviews, three cases were chosen, based on the empirical findings from the questionnaire as well as other related research in the industry. The three studied cases emphasise different aspects of energy related ESCO activity in the Swedish PPI and by so contribute to increased knowledge of the complex issue of different forms of energy efficiency services. The definition of such energy efficiency measures and energy efficiency services are derived, in section 5 in this paper, from the European Commission's definition (EC, 2006). Among the studied outsourcing cases one was an integrated pulp and paper mill (Case 2) while the other two were non-integrated paper mills (Case 1, Case 3).

Altogether six in-depth interviews were conducted with the person responsible for energy matters at six different mills. Three respondents at three mills, with leading experience of current and past collaborations between PPIs and ESCOs, as well as three respondents at three mills without any energyrelated outsourcing activities, were interviewed. As regards the latter interviews these were used as a "shadow control" to validate if the results from the outsourcing cases were plausible (Vedung, 1998). Issues covered in the interviews included the effect on the outsourced business activity, the innovation process, information and contact with the outsourced business activity, and hidden costs and dependence on the new supplier (the ESCO). As regards the interviews with respondents at mills without any ESCO cooperation, the interview covered issues concerning why the mill had not been involved in outsourcing cooperation. The interviews took about one hour, and was partly transcribed and sent back to the respondents for approval. The interviews were further complemented with other empirical material from the three outsourcing cases such as the company's own energy audits, articles in energy journals, annual reports etc. The cases were anonymized before inclusion in this paper. The reasons for doing so were that the respondents demanded it for reasons of business and contractual secrecy, and that this thus plausibly increases the validity of the research.

\section{Core business and outsourcing}

As stated previously, in Möllersten and Sandberg (2004) several reports from both the USA and Sweden indicate that manufacturing firms, both energy intensive and non-energy intensive, today have fewer resources for non-core activities such as maintenance and operation of energy facilities. This is due to the fact that the companies are increasingly focusing their efforts on their core competences and core businesses areas (Möllersten and Sandberg, 2004; Greenbaum, 2001; Nilsson et al., 1996). This means that even though the energy 
intensive industries, and in particular the PPI, have energy costs in relation to the added value of well over 20 percent (SEA, 2000), energy management and energy related business areas may not qualify as core business areas, and will therefore not be highly prioritized (Möllersten and Sandberg, 2004).

Since the beginning of the 1990s one significant trend in business strategy has been to strategically focus on core business (Markides, 1992). Markides (1992) argues that the reason behind the increased focus on core business was that many firms had diversified beyond their optimal diversification limits and performed poor profitability. As a reaction to firms' high diversification and its suggested negative implications, the strategic focus moved towards the firm's core businesses. The concept of 'core businesses', as described by Markides (1992), became a theoretical tool to capture an organization's major or essential business activities. By concentrating on its core business, a firm could move back, closer to its optimal diversification levels, implying that refocusing would help the firm to improve its profitability and market value (Markides, 1992). Since the 1990s, several firms, on global level, has thus divested unrelated business activities (Markides, 1992). A similar trend can be observed in Sweden. Since the beginning of the 1990s, major Swedish corporations have reduced their level of diversification and increased their focus on fewer business areas (Bengtsson, 2000).

Slimmer organizations have consequently emerged by means of outsourcing and divesting business activities. Over the last two decades outsourcing of business activities that are perceived to lie outside of the firm's core business has increased. Outsourcing could be defined as the transfer of the management and performance of an entire business function to an external service provider. According to the supporters of outsourcing, this leads to cost reductions, access to unique expertise, and differentiation (Berggren and Bengtsson, 2004). This is due to the fact that the non-core activities do not receive the full attention of company management, which means that performance improvements in these areas are rare. By outsourcing these business activities another company can make the activity their core business.

The strategic decision whether to outsource business activities or not is a complex one and depends, among other factors, on if the technology is key to competitive advantages. It is also in general terms more feasible to outsource a less complex technology than the opposite. Outsourcing may thus be a feasible solution if the technology is not a key to competitive advantages, is less complex and if the technological expertise is inadequate in the company (Johnson et al., 2005 p. 484-487).

As Hendry (1995) states, there are also important factors such as management fashion and political ideology that accentuate the importance of outsourcing. Previous research has also found a number of potential risks associated with outsourcing such as less control over the outsourced business activity, a reduced innovation process due to the fact that the company loses the daily information and contact with the outsourced business activity as well as hidden costs and dependence on the new supplier (Insinga and Werle, 2000; Hendry, 1995; Utterback, 1996; Wasner, 1999).

\section{ESCOs}

In relation to energy, outsourcing of the energy supply, energy use and the operation and maintenance of the facilities in different industries to an external party have been commonly referred to as energy services (ESs), where the parties offering the service are called energy service companies (ESCOs).

The concept of ESCOs is sprung from the US as a consequence of the oil crises of the early 1970s and later came to be referred to as demand side management (DSM). The term "negawatt" was introduced which meant that instead of investing in new power production, the power company could lower their customers' energy use or shift power loads by load management, and by this means avoid investment in a new power plant. The concept of ESCOs has since then spread outside the US and is, for example in the European Union, considered to be one of the major means to reduce the Union's use of energy by 9 percent $(\mathrm{EC}, 2006)$. Research of the ESCO industry in Europe has found that ESCOs could play an important role in promoting energy efficiency (Vine, 2005). Bertoldi et al., (2006), however, have shown that major differences still exist in the development of the ESCO market in Europe. In some European countries ESCOs have been operating for several years, while in others ESCOs did not exist until very recently (Bertoldi et al., 2006). Bertoldi et al (2006) demonstrated that the difference in the use of ESCOs is due to, e.g. different levels of support offered to ESCOs by national and regional energy authorities, local market structures and rules, and variation in the definitions, roles and activities of ESCOs (Bertoldi et al., 2006). Sorrell (2007) argues that ESCOs may only be useful for some industries and that it is of importance to spot sectors where ESCOs could most appropriately be utilized (Sorrell., 2007). Given Chinas substantial energy use and its economic growth, a recent study analyzed the potential role of ESCOs in China, showing that a number of barriers exists inhibiting the utilization of ESCOs in the country (Da-li, 2009).

In 1978, the first ESCO appeared in Sweden, and in 2001 there were between 6 and 12 Swedish ESCOs with a total value of about 30 million USD (Vine, 2005). Research of the ESCO industry within the Swedish PPI include, for example, Möllersten and Sandberg (2004), who found that the two main barriers to the utilization of ESCOs were that the ESCOs must prove that they can bring added value, other than capital, to pulp and paper mills, and the lack of competition between external energy service providers. Another study covering the role of ESCOs in, among other sectors, Swedish PPIs, found that "the supply of energy efficiency services does not result in a more efficient use of energy - neither from the viewpoint of public economics nor from the viewpoint of business economics" (Bergmasth and Strid, 2004).

\section{Analyzing the role of ESCOs in the Swedish pulp- and paper industry}

Empirical results from the questionnaire 
This section presents the empirical results from the questionnaire. Companies' trust in different sources of information concerning energy efficiency has been stated to be of major importance if energy efficiency measures are to be undertaken (Sorrell et al., 2000). In Fig. 1, the 40 respondents' views of different information sources regarding potential energy efficiency measures are outlined (Thollander and Ottosson, 2010).

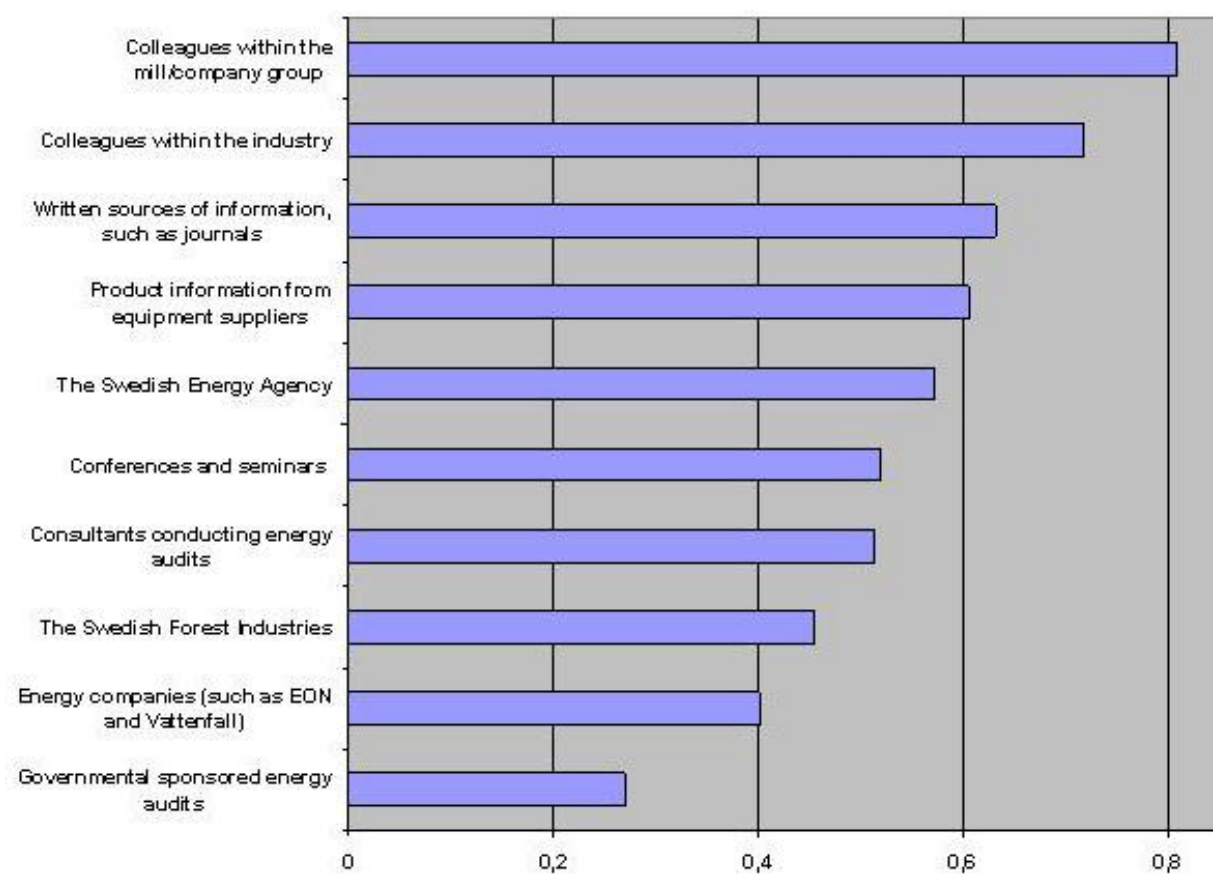

Fig. 1. Ranking of how useful the respondents considered different information sources to be as regards potential energy efficiency measures, 1 point for 'excellent', 0.67 for 'good', 0.33 for 'fair' and 0 for 'not good' (Thollander and Ottosson, 2010).

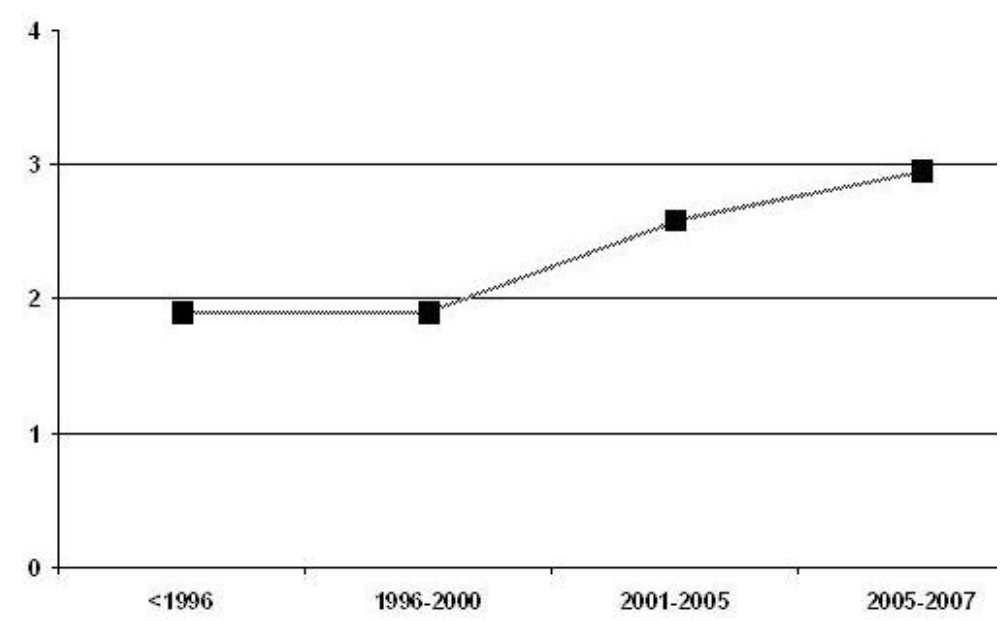
One concluding remark is thus that the Swedish PPIs' conviction seems to be that the industry considers itself to be the party with the 'best' knowledge about potential energy efficiency measures. This further accentuates the need for a deeper understanding of why this is the case leading to the interview study section of this paper, which is presented below.

CASE 1 - The outsourcing of a paper mill's facilities

The paper mill is part of a large multinational company group and is one of the world leaders in its market segment. In the early 2000 s the company group outsourced all their facilities to a foreign based facility company. The facility company in turn hired an ESCO company for the operation and maintenance of the mill's facilities. In the case of the studied paper mill, this affected the back-up boilers, lighting, pumps, fans and ventilation etc. that are now being operated and maintained by the ESCO. It should, however, be noted that the main process boiler is still owned by the paper

Fig. 2. Ranking of how the respondent considered the mill's/company group's priority of the energy issue to have changed since 1996, for the different time periods outlined in the figure. $3 \mathrm{p}$ for 'increased priority', $2 \mathrm{p}$ for 'unchanged priority', $1 \mathrm{p}$ for 'decreased priority'. mill. Energy related decisions are normally restricted by a one-year payoff requirement within the company group. All investments above about 100,000 EUR have to be approved by the paper mill's company board, which is also located abroad. The interviewed respondent at the mill was in charge of the maintenance department where all energy related issues are dealt with. 
During the interview the respondent specified a number of problems with the outsourcing of the mill's facilities to the ESCO. The initial idea behind the concept was that the paper mill alone should handle all production related issues while the ESCO should handle all the non-production related issues concerning the facilities. This separation, however, according to the respondent, has been impossible to maintain. For instance, the respondent stated that when one particular energy efficiency investment was not approved by the foreign based facility company, the paper mill had to hide the investment from them. The respondent states: "We made it (the investment) at the facility by calling it a surrounding facility, so today it does not exist in the foreign facility company's documents. We hid the investment." The respondent further states: “...some stuff (investments) are not anyone's responsibility and are fuzzy. Really, what is this - is it theirs or is it ours?"

The above quotes exemplify how different energy efficiency investments literally fall in no man's land between the different owners' responsibilities, i.e. the facility company, its corresponding ESCO, and the paper mill. The respondent went on to explain that the paper mill's costs had increased as a result of the facility outsourcing. Furthermore, the respondent also stated that an energy efficiency investment today includes considerably longer decision chains than was the case before the outsourcing, i.e. the transaction costs had increased. This was manifested by the respondent as: "I have to call the foreign based facility manager and say 'Hey, now your boiler is starting to wear out, I think we have to take a look at it before the next budget.' Then it is up to him to make the decision whether to replace it or not.". The studied case indicates that the outsourcing of the facilities to the ESCO has resulted in an increased magnitude of barriers to energy efficiency such as lack of incentives to reduce energy costs and longer decision chains. This may be seen as an effect of a split incentive which increases an investment's hidden costs. A split incentive refers to when a person or department cannot gain benefits from an energy efficiency investment, probably leading to the implementation being of less interest (Jaffe and Stavins, 1994). Hidden costs refer to costs associated with investments that are not reflected in commonly used investment calculations such as the payback method. This causes the hidden costs to be ignored in the investment calculation (Ostertag, 1999).

CASE 2 - The outsourcing of an integrated pulp and paper mill's internal process boiler

The integrated pulp and paper mill produces a special type of paper and has two main internal boilers, both mainly biomass-fuelled. At the end of the 1990s a strategic decision was taken by the company board to outsource one of the main boilers to a Swedish ESCO. The ESCO invested approximately 50 million EUR in a new boiler and an 18-year contract was signed between the ESCO and the paper mill. The ESCO owns the boiler, which delivers all the electricity and steam produced direct to the paper mill's production process. In order to evaluate the studied mill's outsourcing project, an interview was conducted with the technical executive, who also is in charge of energy and environmentrelated issues at the mill. The respondent states: "the boiler is located on our site and they deliver all the steam and electricity to us. It is our staff that run the boiler together with other process-related equipment. It is our staff that perform the maintenance. Chemicals etc are delivered through our management. So in all essentials, it is our staff that run and maintain the whole activity. There is one person from the ESCO that visits us regularly, on a weekly basis. They thus still have a responsibility for the activity and keep in touch by telephone." If the mill wants any boiler-related change to take place, the ESCO and the mill staff arrange a meeting as the ESCO is in charge of all new boiler-related investments. Why then was the initial decision taken by the mill at the end of the 1990s to outsource one of its main internal boilers to the ESCO? The respondent states that: "It was economically beneficial for both parties. It was for financial reasons. There were expectations regarding increased energy efficiency. I know that we said at the time of the investment that we believed that it would be advantageous to affiliate a partner that is capable concerning energy issues.". This idea is verified by the MD of the paper mill who in a Swedish energy journal stated that: "The project combines the ESCOs' competence in the energy area with our experience of paper production." It was further stated that: "We will achieve significant environmental improvements and simultaneously increase our cost efficiency. Furthermore, we release resources to develop our business within other areas".

The respondent at the mill states that it is a wellfunctioning cooperation. However, the high expectations at the end of the 1990s were not fully realized, not least with regard to increased energy efficiency. The respondent states: "I believe that there existed, perhaps this is a personal view, a greater expectation that the ESCO could contribute with knowledge concerning burning etc. However, it is different to run a district heating boiler, that could be shut down during the summer and then be able to maintain it, compared to this sort of boiler that in principle is running at maximum load all the time." This indicates that the ESCO's competence in other types of heating supplies, e.g. district heating, may not be transferable to the complex and continuous production process within the PPI. It should be noted that from a financial point of view, the outsourcing project released resources to the mill but from an energy efficiency point of view, the project has not led to any significant improvements.

The respondent at the studied mill was asked to comment on the question of whether the mill's other main internal process boiler, the recovery boiler, could be outsourced: "Everything is possible. I don't believe that it would be the most efficient way to run production. I believe that you should keep the process under single ownership to gain the best total efficiency. Yes, it is possible but I don't believe it is the best method".

CASE 3 - The outsourcing of a paper mill's external boilers

The paper mill is part of a foreign based multi-national company group and produces tissue. The mill has three paper machines and uses only virgin pulp, which is bought from market pulp producers. About $90 \%$ of the produced tissue is exported. In 1996 the company took the strategic decision to 
outsource their entire steam central, consisting of one main process boiler that combusts wood chips and two back-up/top load oil-burning boilers. The steam central is situated outside the mill's facilities and was in need of some investments that the company group considered too expensive at the time. The ESCO contacted the mill and an agreement was reached in 1996. The main reasons behind the decision to outsource, however, were financial, but tax issues also affected the decision. By using another company that sold the biomass generated steam and heat to the paper mill, tax reliefs could be obtained. At the beginning, there were no energy efficiency motives behind the outsourcing. It should, however, be stated that at this time the mill's energy costs were only the third biggest cost, with raw material number one and staff number two. Since then, energy costs have increased by a factor of 5 and are now the second largest cost.

In the deal between the mill and the ESCO, the ESCO took over the maintenance, the personnel and the investments needed in the steam central. The interviewed respondent at the mill, who has been in charge of the energy issue for a number of years, stated that: "And in retrospect I can only state that it was one of the wiser decisions I have ever taken". Before the outsourcing the steam central was rather neglected. The respondent states: "The availability of steam that we have had since the ESCO took over did not exist when we ran the activity ourselves". One explanation for this is also that the ESCO made some much needed investments in both a new back-up boiler and the fuel-feeding system to the main biomass boiler. According to the respondent, the effects have therefore been increases in cost- and energy effectiveness and security of energy supply. The increase in energy efficiency is due to: "Better control systems, better techniques in the handling of the fuel and staff education." In the early 2000s, another ESCO with a more regional association bought and took over the ESCO activity from the previous ESCO. This in turn has led to even better cooperation according to the respondent. The factors behind the success, according to the respondent, are: "A functioning contract and a functioning continuous dialogue." The contact with the outsourced steam central is handled both at operational and managerial level, depending on the impact and size of the issue. The respondent sums up the benefits of the outsourcing by stating: "The activity that we shall be really good at is making tissue; we do not own any hydropower plant for generating electricity. Why do we need a steam central? There are people that are specialists in running those with state-of-the-art technology and control systems etc." Even though the respondent was very positive to the outsourcing he would not outsource a boiler that is more integrated in the production process, such as a recovery boiler. The fact that the mill's boilers are external to the mill is in fact a major explanation for the success in this case.

\section{Concluding discussion}

The aim of this study was to describe and analyze the role of ESCOs as a method to promote energy efficiency in the Swedish PPI. As shown in the questionnaire, the Swedish PPI's confidence in information concerning energy related issues coming from ESCOs, is at present considerably low.
This is surprising, considering the fact that there already exist several energy related outsourcing agreements between ESCOs and mills, and considering the fact that the PPIs' have been giving energy issues higher priority since 1996. The cases studied in this paper, however, have given some answers to why this is the case. Minor explanations for this are that personal relationships between different staff at the mill and the ESCO have to function if the outsourcing is to be successful. A well-functioning contract and a continuous dialogue have also been stated to be important. However, this is not solely related to the PPI and does not explain the low utilization of ESCOs in the studied industry

As shown in case 1, the paper mill's multinational company group took the decision to outsource their facilities, comprising back-up boilers, lighting, pumps, fans and ventilation etc., to a foreign based facility company in the early 2000s. The paper mill's main boiler, however, was never outsourced due primarily to the perceived risk of production disruptions. In Case 2, however, another paper mill's business group took the opposite decision, to outsource one of the main internal process boilers, while the rest of the mill's facilities remain under the mill's control. In Case 3, the entire steam central, with all three external boilers, was outsourced to an ESCO.

In case 1 , the respondent was considerably dissatisfied with the outsourcing, stating that an energy efficient investment today includes longer decision chains (and thus increased hidden costs) and lower incentives than was the case before the outsourcing. This indicates that barriers to energy efficiency such as hidden costs and split incentives have in fact increased. Case 2 represents a case were the expectations from the ESCO and the outsourcing agreement were high initially, but where the mill's staff themselves run and maintain the whole activity today. In financial terms the cooperation was a good deal, but concerning the initial expectations concerning significant environmental improvements and energy efficiency this has not proved to be the case. One conclusion from this case is that the ESCO's competence in other types of heating supplies, e.g. district heating, may not be transferable to the complex and continuous production process within the PPI. In case 3 , the main reasons for the outsourcing were financial and taxrelated, but the outsourcing also resulted in energy efficiency, due to the fact that the ESCO brought better control systems, better techniques in the handling of the fuel, and staff education. Case 3 thus represents a case were the mill's respondent was more than satisfied with the outsourcing of its external boilers to an ESCO.

In general terms, in all three cases the main motive behind the decision to outsource energy-related activities such as facilities, external and internal boilers were financial or taxrelated. In case 3, however, it also resulted in a higher degree of cost- and energy efficiency, as well as increased security of supply, while the result was quite the opposite in case 1 . The strategic decision whether to outsource business activities or not are, as previously stated, a complex one, and depends among other factors on if the technology is key to competitive advantages. It is also, in general terms, more feasible to outsource a less complex technology than the opposite. 
Outsourcing may, as stated earlier, be a feasible solution if the technology is not key to competitive advantage, is less complex, and if the technological expertise is inadequate in the company (Johnson et al., 2005). This in turn leads us to the main conclusion from this paper that is shown in Fig. 3.

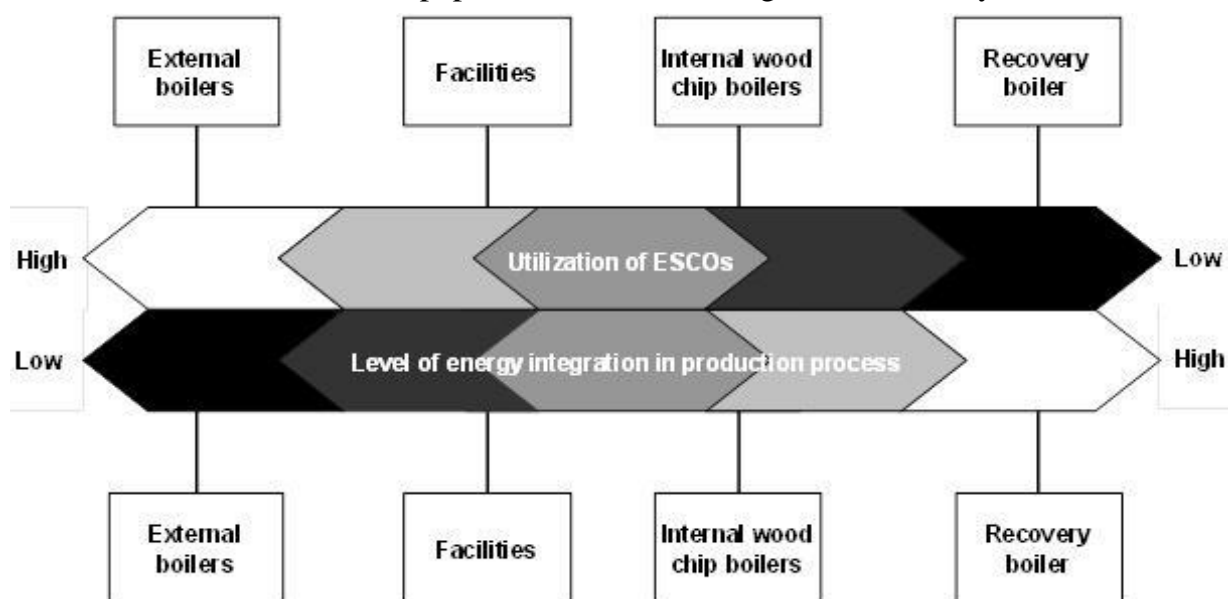

Fig. 3. Utilization of ESCOs versus the level of energy integration in the Swedish pulp and paper industry regarding spotted outsourcing cases.

As demonstrated in Fig. 3., the utilization of ESCOs in the Swedish PPI is higher in activities with a lower level of energy integration in the production process. Conversely, the utilization of ESCOs is lower with a higher level of energy integration in the production process. This means that a successful outsourcing agreement is more probable if it concerns external boilers that have a low level of integration in the production process. On the other hand, it is less likely that a successful outsourcing agreement will be reached if it concerns the recovery boilers, with a high degree of energy integration in the production process. As demonstrated in case 2 , the internal process boilers are complex to run and the technological expertise demanded are usually higher at the mill. It could further be stated that the technology is a key to competitive advantages since the internal boilers, and in particular the recovery boiler, are the "heart" of the whole integrated pulp and paper production, and unplanned stops in the production are very costly and immediately affect the mill's profitability. On the other hand, the ESCO's competences from other types of heating supplies, e.g. the district heating, were more appropriate in Case 3, where the paper mill did not itself have the competence, or did not prioritize running the external boilers in its steam central. The fact that the paper mill's boilers are external to the mill is a major explanation for the success in this case.

In conclusion, this study of the Swedish PPI has shown that the utilization of ESCOs in this industry is likely to be higher in activities with a lower level of energy integration in the production process, and thus lower with a higher level of energy integration in the production process. Since the PPI is a mature industry with a globally well-known and well-spread technique, results from this paper, plausibly holds even for PPIs in other countries, apart from Sweden.

Finally, theoretically, the authors wish to leave one final remark. The notion of core business and outsourcing of energy-related issues would most likely benefit from an inclusion of a widened view of what may or may not be considered a long-term "competitive advantage". Such a widened view should incorporate a thorough strategic risk analysis, i.e. for several years ahead, including risks of price increases for raw material and energy, cost for personnel etc. Looking in the historical lens some twenty years back, such a widened view would have reduced the risk of the costly re-considerations and reinvestments in regard to energy and raw material, which have occurred after the adoption of these concepts. However, we leave the challenge to formulate such a widened view and theory, an area for future research.

\section{Acknowledgments}

The work has been carried out under the auspices of the Energy System Programme, which is financed by the Swedish Energy Agency. We kindly thank the respondents at the studied mills for giving freely of their time to answer the questions. We would also like to thank the two anonymous reviewers for valuable comments on earlier drafts of this paper. The usual disclaimer applies.

\section{References}

1. Bengtsson, L. (2000). Corporate strategy in a small open economy: Reducing product diversification while increasing international diversification. European Management Journal, 18(4), 444-453.

2. Berggren, C., Bengtsson, L., 2004. Rethinking outsourcing in manufacturing - a tale of two telecom firms. European Management Journal, 26 (5), 314-324.

3. Bergmasth, M., Strid, M., 2004. Energitjänster på en avreglerad marknad - för en effektivare energianvändning? (Energy services in a deregulated market-for a more efficient use of energy?), Dissertation, School of Economics and Commercial Law, Gothenburg University, Gothenburg.

4. Bertoldi, P., Rezessy, S., Vine E., 2006. Energy service companies in European countries: Current status and a strategy to foster their development. Energy Policy 34, 1818-1832.

5. Bjuggren, P.O., 1985. A Transaction Cost Approach to Vertical Integration: The Case of the Swedish Pulp and Paper Industry. Lund Economic Studies No. 38. Doctoral Dissertation, Lund University, Lund, Sweden.

6. DS, 2001. Departementsserien 2001:65. Förslag till program för långsiktiga avtal med energiintensiv industri Energieffektivisering och andra åtgärder för att minska utsläppen av klimatpåverkande gaser. (Proposals for a program for long-term agreements with the energy intensive industry - Energy efficiency and other measures aimed at reducing emissions of greenhouse gases). Fritzes, Stockholm (in Swedish). 
7. EC, (European Commission) 2006. Directive 2006/32/EC of the European Parliament and of the Council of 5 April 2006 on energy end-use efficiency and energy services and repealing Council Directive 93/76/ EEC, Brussels.

8. Ernst \& Young, 2007. The art of turnaround management. The challenges of change in the paper industry.

9. Eurostat, 2007. Final energy consumption, by sector. Retrieved October 25, 2007, from Eurostat's web site: http://epp.eurostat.ec.europa.eu/portal/page?_pageid = $1996,39140985 \&$ \&dad $=$ portal\&_schema = PORTAL\&screen $=$ detailref\&language $=$ en\&product $=$ sdi_cc\&root = sdi_cc/sdi_cc/sdi_cc_ene/sdi_cc2200.

10. Da-li, G. 2009. Procedia Earth and Planetary Science 1(1), 1695-1704.

11. Greenbaum, P., J., 2001. Spending money elsewhere. Pulp \& Paper Canada, 102 (2), 11-14.

12. Hendry, J., 1995. Culture, community and networks: the hidden cost of outsourcing. European Management Journal, 13, 193-200.

13. Hrickiewicz, M., 1999. Outsourcing for plant utilities. Chemical Processing, 62 (11) p. 67-71.

14. Insinga, R., C., Werle, M., J., 2000. Linking outsourcing to business strategy. Academy of Management Executives, 14 (4), 58-70.

15. IPCC, 2007. Contribution of Working Group III to the Fourth Assessment Report of the Intergovernmental Panel on Climate Change. Summary for Policymakers. Retrieved $\begin{array}{llll}\text { October } & \text { 8, } & \text { from }\end{array}$ http://www.ipcc.ch/SPM040507.pdf.

16. Jaffe, A., Stavins, R., 1994. The energy-efficiency gap: what does it mean? Energy Policy, 22 (10), 804-810.

17. Johansson, B., Modig, G., Nilsson, L.J., 2007. Policy instruments and industrial responses - experiences from Sweden. In: Proceedings of the 2007 ECEEE summer study "Saving energy - just do it", Panel 7. European Council for an Energy-Efficient Economy, 1413-1421.

18. Johnson, G., Scholes, K., Whittington, R., 2005. Exploring Corporate Strategy: Text and Cases. Financial TimesPrentice Hall, Harlow, UK.

19. Laestadius, S., 1998. Technology level, knowledge formation, and industrial competence in paper manufacturing. In G,. Eliason, C., Green, C., R., McCann (Eds.) Microfoundation of economic growth: A Schumpeterian perspective. Ann Arbor, MI: The University of Michigan Press.

20. Markides, C. C. (1992). Consequences of corporate refocusing: Ex ante evidence. Academy of Management Journal, 35(2), 398-412.

21. Merriam, S., 1998. Qualitative research and case study applications in education. San Francisco : Jossey-Bass.

22. Möllersten, K., Westermark, M., 2001. Outsourcing of energy facilities in the pulp and paper industry - motives for outsourcing partnerships between energy companies and pulp and paper manufactures. Paper presented at World Energy Council, 18th Congress, Buenos Aires.

23. Möllersten, K., Sandberg, P., 2004. Collaborative energy partnerships in relation to development of core business focus and competence - A study of Swedish pulp and paper companies and energy service companies. Business strategy and the Environment, 13, 78-95.

24. Nilsson, L., Larson, E., Gilbreath, K., Gupta, A., 1996. Energy efficiency and the pulp and paper industry. Report number IE962. Washington, DC: American Council for an Energy-Efficient Economy.

25. Ostertag, K., 1999. Transaction Costs of Raising Energy Efficiency. In: Proceedings of the 2007 IEA International Workshop on Technologies to Reduce Greenhouse Gas Emissions: Engineering-Economic Analyses of Conserved Energy and Carbon.

26. SCB, 2006. SCB's statistical database, statistikdatabas, Retrieved October 8, 2007, from Statistics Sweden's web site: www.scb.se.

27. SEA, (Swedish Energy Agency) 2000. Energianvändning inom industrin (Energy use within the industry). Swedish Energy Agency Publication Department, Eskilstuna (in Swedish).

28. SEA, (Swedish Energy Agency) 2007a. Energy in Sweden 2006, Facts and figures. Retrieved October 8, 2007, from the Swedish Energy Agency's web site: http://www.energimyndigheten.se/web/biblshop.nsf/ FilAtkomst/ET2006 44.pdf/\$FILE/ET2006_44.pdf?OpenElement.

29. SFI, (Swedish Forest Industries) 2005. Energiförbrukning i massa- och pappersindustrin 2000 (Energy use in the pulp and paper industry 2000). Retrieved October 8, 2007, from the Swedish Forest Industries' web site: http://www.skogsindustrierna.se/LitiumDokument20/Get Document.asp? archive $=3 \&$ directory $=27 \&$ document $=$ 257 (In Swedish).

30. SFI (Swedish Forest Industries), 2007. Retrieved October 8, 2007, from the Swedish Forest Industries's Web site: http://www.skogsindustrierna.se/LitiumInformation/site/pa ge.asp?Page $=10 \&$ IncPage $=626 \&$ Inc Page2 $=$ $232 \&$ Destination $=227 \&$ destination $2=226 \&$ ohKatID $=$ $5 \&$ ohID $=13 \&$ lang $=$ sv .

31. Sorrell, S., Schleich, J., Scott, S., O’Malley, E., Trace, F., Boede, E., Ostertag, K. Radgen, P., 2000. Reducing Barriers to Energy Efficiency in Public and Private Organizations. Retrieved September 16, 2008, from SPRU's (Science and Technology Policy Research) web site: http://www.sussex. ac.uk/Units/spru /publications/reports/ barriers/final.html

32. Sorrell, S., 2007. The economics of energy service contracts. Energy Policy 35 (2007) 507-521.

33. Thollander, P., Ottosson, M., 2010. Energy management practices in Swedish energy-intensive industries. Journal of Cleaner Production (18):125-133.Thollander, P., Ottosson, M., 2008. An energy efficient Swedish pulp and paper industry - exploring barriers to and driving forces for cost-effective energy efficiency investments. Energy Efficiency, 1, 21-34.

34. Utterback, J., M., 1996. Mastering the dynamics of innovation. Boston, Mass.: Harvard University Business School Press. 
35. Vedung, E., 1998. Utvärdering i politik och förvaltning. (Evaluation in Policy and Administration). Studentlitteratur, Lund (in Swedish).

36. Vine, E., 2005. An international survey of the energy service company (ESCO) industry. Energy Policy 33 (5), 691-704.

37. Wasner, R., 1999. The process of outsourcing : strategic and operational realities. Department of Management and Economics, Divisions of Industrial Marketing, Linköping University, Sweden.

38. Wolf, A., Petersson, K., 2007. Industrial symbiosis in the Swedish forest industry. Progress in Industrial Ecology, An International Journal, 4 (5), 348-362.

39. Yin, R., K., 2003. Case Study Research: Design and Method. Applied Social Research Methods, vol. 5. Sage, London. 